\title{
Kolon Kanseri Hücrelerinde Katlanmamış Protein Cevabının Aşırı Uyarılması VEGF İfadesini ve Salınımını Artırır
}

\author{
Sinem Tunçer ${ }^{1,2 *}$, Ege Solel ${ }^{1,3}$, Sreeparna Banerjee ${ }^{1,4}$
}

Geliș / Received: 10/10/2019

Revize / Revised: 13/02/2020

Kabul / Accepted: 06/03/2020

$\underline{\mathbf{O Z Z}}$

Protein katlanması ve olgunlaşması Endoplazmik Retikulum (ER)'da gerçekleşir. ER fonksiyonundaki bozulmalar, yanlış katlanmış proteinlerin birikmesine neden olur ki bu durum "ER stresi" olarak bilinir. Katlanmamış Protein Yanıtı (Unfolded Protein Response-UPR), ER stresi durumunda hücresel homeostazın sağlanması için ER'de protein katlanmasının yeniden ve doğrulukla gerçekleştirilmesi amacı ile düzenlenmiş bir hücre sinyalizasyon programıdır. Bu çalışmada ER stresinin, kolon kanseri hücrelerinde Vasküler Endotelyal Büyüme Faktörü (VEGF) ifadesini ve VEGF'nin hücre dışı salınımını en az iki kat arttırdığı gösterilmiştir. ER stresi modülatörleri kanser hücrelerinde ER stresine bağlı apoptozisi tetikleme potansiyelleri ile umut verici tedavi seçenekleri olarak sunulsa da, bu çalışma sonucu elde edilen veriler, ER stresini tetikleyici yaklaşımların, artmış otokrin/intrakrin VEGF sinyali ile tedaviye karşı dirence neden olabileceğini, hatta anjiyogenezi destekleyebileceğini öne sürmektedir.

Anahtar Kelimeler- Kolorektal kanser, VEGF, VEGFR, Katlanmamış Protein Yanıtı (UPR), ER stresi

1 Department of Biological Sciences, Orta Dogu Teknik Universitesi, Ankara 06800, Turkey

${ }^{2 *}$ Corresponding author e-mail: sinem.tuncer@bilecik.edu.tr(https://orcid.org/0000-0002-8947-8646)

Present address: Vocational School of Health Services, Department of Medical Laboratory Techniques, Bilecik Şeyh Edebali University, Bilecik, 11230, Turkey

Biotechnology Application and Research Center, Bilecik Şeyh Edebali University, Bilecik, 11230, Turkey

3e-mail: egesolel@gmail.com (https://orcid.org/0000-0003-1120-0190)

Present address: Department of Biomedicine, University of Bergen, Bergen, Postbox 7804, N-5020, Norway

${ }^{4}$ e-mail: banerjee@metu.edu.tr (https://orcid.org/0000-0003-4596-6768)

Department of Biological Sciences and Cancer Systems Biology Laboratory (CanSyl), Orta Dogu Teknik Universitesi, Ankara 06800, Turkey 


\title{
Extensive Unfolded Protein Response Stimulation in Colon Cancer Cells Enhances VEGF Expression and Secretion
}

\begin{abstract}
Endoplasmic Reticulum (ER) is an important site for protein folding and maturation. Accumulation of unfolded or misfolded proteins in the ER leads to "ER stress". The unfolded protein response (UPR) is a finely regulated cell-signaling program to re-establish ER folding capacity for building up cellular homeostasis. Although ER stress modulators have emerged as promising treatment options with their potential to trigger ER stress-mediated apoptosis in cancer cells, here we show that ER stress upregulates Vascular Endothelial Growth Factor (VEGF) expression and secretion by at least two fold in colon cancer cells, which may result in resistance against the treatment through enhanced autocrine/intracrine VEGF signaling and through supporting further angiogenesis.
\end{abstract}

Keywords- Colorectal cancer, VEGF, VEGFR, Unfolded Protein Response (UPR), ER stress 


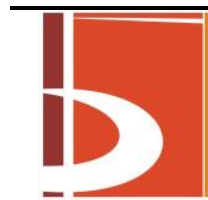

BiLECIK SEYH EDEBAL UNIVERSITESI
BŞEÜ Fen Bilimleri Dergisi

7. Cilt - Milli Mücadele ve TBMM'nin

Açılışının 100. Yılı Anısına-100. Yıl Özel

Say1s1

329-343, 2020
BSEU Journal of Science

DOI: 10.35193/bseufbd. 631769

e-ISSN: $2458-7575$ (http://dergipark.gov.tr/bseufbd)

\section{INTRODUCTION}

Cancer cells encourage the development of new blood and lymphatic vessels from the preexisting ones to handle with their oxygen and nutrient demand and favor tumor outgrowth. Angiogenesis can be defined as new blood vessel formation and sprouting of endothelial cells from pre-existing vasculature [1]. Various growth factors are known to be involved in tumor angiogenesis, but among them the family of Vascular Endothelial Growth Factors (VEGFs) has been demonstrated to be a major contributor to angiogenesis [2]. The VEGF family includes five highly related proteins, VEGF-A, VEGF-B, VEGF-C, VEGF-D, PIGF (Placenta Growth Factor), the virus-encoded VEGF-E and the snake venom-derived VEGF-F; of these, VEGF-A, simply referred as VEGF, is the prototypical molecule [3, 4].

There are four major isoforms of VEGF, $\mathrm{VEGF}_{121},-{ }_{-165},-189$, and -206, named based on the number of the amino acid residues. Among these splice variants, $\mathrm{VEGF}_{165}$ is the most prevalent and most important isoform involved in neovascularization [4, 5]. VEGF binds to VEGFR1/Flt1 and VEGFR2/KDR/Flk1 receptors, primarily expressed by vascular endothelial cells (ECs) [6]. Despite its higher affinity for VEGF, tyrosine kinase activity of VEGFR1 is approximately ten times weaker than that of VEGFR2 [7]. Therefore, major proangiogenic signals are supposed to be generated from the ligand-activated VEGFR2 [6]. Following ligand binding, VEGFR2 dimerizes and undergoes autophosphorylation. The activated receptor enhances intracellular calcium through PI3K (phosphotidylinositol-3 kinase)/AKT (Protein Kinase B) signaling, which activates eNOS (endothelial Nitric Oxide Synthase) by CaM (Calmodulin) binding as well as by direct phosphorylation, resulting in increased NO (Niric Oxide) production. On the other hand, downstream signaling from PI3K/AKT can cause direct phosphorylation of eNOS providing a more sustained, calcium-independent stimulus to enhance eNOS activity. VEGFR2 signaling also stimulates the conversion of PIP2 (phosphatidylinositol 4,5-bisphosphate) to DAG (Diacylglycerol) and IP3 (Inositol 1,4,5-trisphosphate) through the activation of PLC $\gamma$ (Phospholipase C gamma). IP3 can mediate an increase in intracellular calcium, whereas DAG can stimulate PKC (Protein Kinase C) which then activate MAPKs (Mitogen-Activated Protein Kinases). These pathways are ultimately responsible for the biological consequences of VEGF signaling in endothelial cells, including migration, enhanced vascular permeability, vasorelaxation, survival, and proliferation [8].

Several mediators, such as growth factors, hypoxia, serum deprivation and osmotic tension are known to modulate the expression and release of VEGF from cancer cells [9]. In colorectal cancer (CRC), increased expression of VEGF family members was found to be associated with cancer risk and tumor tissue protein levels of VEGF and VEGFR were shown to be significantly correlated with the tumor size, tumor stage, tumor site, patient's age, and lymph node metastasis [10]. Anti-angiogenic therapies mainly focus on the generation of blocking molecules to inhibit VEGF-VEGFR interactions or to inhibit the activity of the VEGFRs, since VEGFVEGFR signaling can occur in a paracrine or autocrine fashion in endothelial cells [11]. On the other hand, most cancer cell types are found to express both VEGF and its receptors [12] and the number of studies indicating a role of autocrine and intracrine VEGF signaling in growth and survival of cancer cells is increasing [12-17].

Endoplasmic Reticulum stress (ER stress) occurs when ER homeostasis is disrupted by several physiological and pathological stimuli, which result in accumulation of unfolded or misfolded proteins in the ER lumen. Deregulated ER activity causes the activation of Unfolded Protein Response (UPR) to restore cellular homeostasis or to trigger cell death [18]. UPR aids cells to restore ER homeostasis by attenuating protein synthesis, by enhancing ER protein folding and processing capacity and by promoting the ER-Associated Degradation (ERAD) pathways to mitigate ER stress [19]. Therefore, UPR can be described as the process in which cells can adapt to the new conditions. However, when ER stress cannot be resolved, the UPR induces persistent and severe ER stress which can kill cancer cells by inducing apoptosis, autophagy, necroptosis, or immunogenic cell death. Thus, use of UPR modulators has been suggested as an innovative and a promising option for patients in whom chemotherapy or radiotherapy have failed [20]. On the basis of this rationale, many drugs have been designed to trigger irreparable ER stress in cancer cells by targeting the key signaling pathways involved in the ER stress response, such as PERK-ATF4-CHOP, ATF6, and IRE1-XBP1s. However, the duration and severity of ER stress may play an critical role in drug responses, which in turn increases cell tolerance to ER stress [21]. Here, we show that ER stress enhances VEGF expression and secretion in colon cancer cells in vitro which highlights that a possible strategy of alleviating ER stress as a therapeutic option can cause resistance against the treatment through VEGF signaling. 


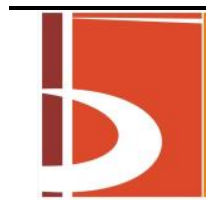

BILECIK SEYH EDEBAL UNIVERSITESI
BŞEÜ Fen Bilimleri Dergisi

7. Cilt - Milli Mücadele ve TBMM'nin

Açılıșının 100. Yılı Anısına-100. Yıl Özel

Say1s1

329-343, 2020
BSEU Journal of Science

DOI: 10.35193/bseufbd. 631769

e-ISSN: $2458-7575$ (http://dergipark.gov.tr/bseufbd)

\section{MATERIALS AND METHODS}

\section{A. Cell Culture and Treatments}

HCT-116 cells were obtained from German Collection of Microorganisms and Cell Cultures (DSMZ, Germany) and grown in 10\% Fetal Bovine Serum (FBS), 1\% penicillin/streptomycin, and 2 mM L-glutamine containing RMPI-1640 medium. Caco-2 cells were purchased from ŞAP Enstitüsü (Ankara, Turkey) and cultured in Eagle's Minimum Essential Medium (EMEM) (Thermo Fisher Scientific, Boston, MA, USA) containing 20\% FBS, $1 \%$ penicillin/streptomycin, $2 \mathrm{mM}$ L-glutamine, $1 \mathrm{X}$ non-essential amino acids, and $1 \mathrm{mM}$ sodium pyruvate. Cells were cultured at $37^{\circ} \mathrm{C}$, in a humidified atmosphere consisting of $95 \%$ air and $5 \% \mathrm{CO}_{2}$.

The cells were incubated for $24 \mathrm{~h}$ with the indicated doses of the ER stress inducing agent tunicamycin (TN; $10 \mathrm{mg} / \mathrm{ml}$ stock in DMSO; Cell Signaling Technology, Massachusetts, USA) or vehicle (DMSO). Where indicated, HCT-116 cells were treated with $25 \mu \mathrm{M}$ of the intracellular $\mathrm{Ca}^{2+}$ chelator BAPTA-AM (25 mM stock in DMSO; Tocris Bioscience, UK) or vehicle (DMSO) for $24 \mathrm{~h}$. Unless stated otherwise, all cell culture consumables were obtained from Biological Industries (Beit Haemek, Israel).

\section{B. Cloning and Transfections}

The $\mathrm{VEGF}_{165}$ overexpression vector was generated by cloning the human $\mathrm{VEGF}_{165}$ coding sequence to pcDNA3.1 (-) mammalian expression vector (Invitrogen, California, USA) through XhoI and HindIII by including Kozak sequence. The human pcDNA-UTR-VEGF 165 , kindly provided by Dr. Ben Zion Levi from Israel Institute of Technology, Haifa, Israel, was used as a template for PCR. The primers:

Forward: 5' GGCCCTCGAGCCACCATGAACTTTCTGCTGTCTTGG 3'

Reverse: 5' GGGAAGCTTTCACCGCCTCGGCTTGT 3' were used to amplify human VEGF 165 for cloning. The cloned vector was confirmed by sequencing.

The day before transfection, HCT-116 cells, seeded as $5 \times 10^{5}$ cells/well on 6-well plate, were transfected with empty pcDNA3.1 (-), which is indicated as EV in the study, or with the $\mathrm{VEGF}_{165}$ overexpression vector, called as VEGF 165 . For transfection experiments, X-tremeGENE HP (Roche, Mannheim, Germany) transfection agent was used according to the manufacturer's directions. To evaluate the effect of TN on viability, day before the transfection, cells were seeded as $5 \times 10^{3}$ cells/well on 96-well plate and after $24 \mathrm{~h}$ transfection with EV or VEGF $_{165}$ overexpression vector, the transfection medium was replaced with complete growth medium and the transfected cells were incubated with $10 \mu \mathrm{g} / \mathrm{ml}$ of TN for another $24 \mathrm{~h}$. Cell viability was analyzed by MTT assay as described below.

For VEGF silencing in HCT-116 cells, $4 \times 10^{4}$ cells were seeded in a 24 -well plate in RPMI-1640 medium supplemented with $10 \%$ FBS and $2 \mathrm{mM}$ L-glutamine. The next day the medium was removed and cells were washed in PBS. To each well, $160 \mu \mathrm{l}$ of siRNA Transfection Medium (sc-36868, Santa Cruz Biotechnology, Dallas, Texas, USA) was added. In an eppendorf tube, for each well, $1.6 \mu$ of VEGF siRNA (sc44278, Santa Cruz Biotechnology) or control siRNA (sc-37007, Santa Cruz Biotechnology) duplex mixed with $20 \mu \mathrm{l}$ of the transfection medium (Solution A). In another tube, $1.6 \mu l$ of siRNA Transfection Reagent (sc-29528, Santa Cruz Biotechnology) was added into $20 \mu \mathrm{l}$ of the transfection medium for each well (Solution B). siRNA duplex solution (Solution A) was added to the dilute Transfection Reagent (Solution B) and mixed gently by pipetting. At the end of 20 min incubation at room temperature, Solution A and Solution B mix was added into the wells containing the transfection medium. After $5 \mathrm{~h}$ of incubation at $37^{\circ} \mathrm{C}, 200 \mu \mathrm{l}$ of RPMI-1640 medium containing $20 \% \mathrm{FBS}$ and $2 \%$ penicillin/streptomycin was added on the wells. Followed by $24 \mathrm{~h}$ incubation at $37^{\circ} \mathrm{C}$, the medium was replaced with RPMI-1640 medium containing $10 \%$ FBS, 2 mM L-glutamine and $1 \%$ penicillin/streptomycin. At the end of an additional $48 \mathrm{~h}$ of incubation, the cells were collected for RNA isolation and the conditioned media were analyzed to determine secreted VEGF levels. HCT-116 cells that were not transfected with siRNA but treated with the transfection agent were used as mock controls.

\section{Evaluation of Cell Viability}

To evaluate the effect of VEGF $_{165}$ overexpression and/or TN treatment on cellular viability, MTT (3(4,5-dimethylthiazol-2-yl)-2,5-diphenyltetrazolium bromide) Cell Proliferation Assay (Vybrant ${ }^{\circledR}$, Thermo Fisher 
Scientific) was used. Briefly, cells were seeded as $5 \times 10^{3}$ cells/well of 96-well plates and allowed to attach overnight. For $\mathrm{VEGF}_{165}$ overexpression, cells were transfected with mammalian expression vector carrying human VEGF $_{165}$ or with empty vector using X-tremeGENE HP (Roche) transfection reagent as described in the manufacturer's instructions. MTT assays were performed at 24 and $48 \mathrm{~h}$ after transfection. To assess the effect of VEGF $_{165}$ overexpression on cell proliferation after $48 \mathrm{~h}$ following the transfection, transfection medium replaced with complete growth medium following transfection for $24 \mathrm{~h}$ and the cells were further cultured for $24 \mathrm{~h}$ before MTT assay. $0 \mathrm{~h}$ was considered as the time point just before transfection. When indicated, transfected cells were incubated with $10 \mu \mathrm{g} / \mathrm{ml}$ of TN or vehicle for $24 \mathrm{~h}$ before MTT assay.

For the MTT assay, the medium was removed from each well at the indicated time points and the cells were incubated for $4 \mathrm{~h}$ at $37^{\circ} \mathrm{C}$ with $1.2 \mathrm{mM}$ of the MTT reagent in $100 \mu \mathrm{l}$ complete growth medium. At the end of $4 \mathrm{~h}$ incubation, $100 \mu \mathrm{l}$ of $10 \% \mathrm{SDS}(\mathrm{w} / \mathrm{v})$ in $0.01 \mathrm{M} \mathrm{HCl}$ was added to each well. The plates were further incubated at $37^{\circ} \mathrm{C}$ for $16 \mathrm{~h}$ to dissolve the formazan crystals. The absorbance of each plate was measured at 570 $\mathrm{nm}$ in a microplate reader (MultiSkan ${ }^{\circledR}$ GO, Thermo Fisher Scientific).

\section{VEGF Secretion Assay}

RayBio $^{\circledR}$ Human VEGF-A ELISA Kit (RayBiotech, Georgia) was used to determine the secreted VEGF-A levels in cell culture supernatants. Secreted VEGF amounts were normalized with total cellular protein amount.

\section{E. Isolation of RNA, cDNA Synthesis, and $q R T-P C R$}

Total RNA isolation was achieved by using NucleoSpin RNA kit (Macherey Nagel, Germany) according to the manufacturer's instructions. cDNA synthesis from DNAse I (Thermo Scientific) treated mRNA was carried out using RevertAid First Strand cDNA Synthesis Kit (Thermo Scientific). Rotor GeneQ 6000 (Qiagen, Germany) was used to carry out qRT-PCR reactions. Fold changes were calculated with respect to the house-keeping gene $\beta$-actin, using the Pfaffl method [22]. qRT-PCR reactions were performed according to MIQE guidelines [23]. For the assessment of VEGF expression

Forward: 5' ATCACGAAGTGGTGAAGTTC 3'

Reverse 5' TGCTGTAGGAAGCTCATCTC 3' primers and for the amplification of $\beta$-actin

Forward: 5' CAGCCATGTACGTTGCTATCCAGG 3'

Reverse: 5' AGGTCCAGACGCAGGATGGCATG 3' primers were used. 40 cycles of PCR reactions were carried out at an annealing temperature of $53^{\circ} \mathrm{C}$.

\section{F. Western Blotting}

Proteins were isolated with M-PER (Mammalian Protein Extraction Reagent, Thermo Scientific) lysis buffer containing phosphatase inhibitor (Roche, Switzerland) and protease inhibitor cocktail (Roche, Switzerland) according to manufacturer's instructions and separated through $10 \%$ SDS-PAGE gels and electrophoretically transferred to PVDF membranes. The antibodies used in the study are shown in Table 1.

Table 1. Antibodies used for western blots in the study.

\begin{tabular}{lll}
\hline Antibody & Vendor & Catalog No \\
\hline VEGF-A & Abcam & ab46154 \\
$\beta$-actin & Santa-Cruz & sc-47778 \\
VEGFR1 & Abcam & ab32152 \\
VEGFR2 & Santa-Cruz & sc-6251 \\
p-VEGFR2 (1059Y) & Abcam & ab195702 \\
p-ERK 1/2 (202T/204Y) & Santa-Cruz & sc-16982 \\
p-AKT (473S) (D9E) XP® & Cell Signaling & 4060 \\
p-SAPK/JNK (183T/185Y) (81E11) & Cell Signaling & 4668 \\
Goat anti-mouse IgG-HRP & Advansta & R-05071-500 \\
Goat anti-rabbit IgG-HRP & Advansta & R-05072-500 \\
\hline
\end{tabular}




\section{G. Analysis of GEO data}

GEO2R tool (ncbi.nlm.nih.gov/geo/geo2r/) was used to identify the changes in VEGF expression across experimental conditions.

\section{H. Statistical Data Analysis}

The results were represented as mean \pm standard error of mean (SEM). Statistical analyses were carried out in Prism 6.01 (GraphPad, La Jolla, California, USA). $t$ test was used to compare two groups $(* \mathrm{p} \leq 0.05, * * \mathrm{p}$ $\leq 0.01, * * * \mathrm{p} \leq 0.001, * * * * \mathrm{p} \leq 0.0001)$.

\section{RESULTS}

\section{A. VEGF is Glycosylated in Colon Cancer Cells}

HCT-116 colon cancer cells were transfected with either pcDNA3.1-VEGF $165\left(\mathrm{VEGF}_{165}\right)$ vector for VEGF $_{165}$ overexpression or pcDNA3.1 empty vector (EV). 24 h post-transfection, cells were lysed and analyzed for the VEGF expression. Of note, since VEGF is a secreted protein, low level of intracellular VEGF protein was detected in EV transfected cells by western blot. As can be seen in Figure 1A, under denaturing conditions, two bands were seen in the VEGF $_{165}$ overexpressing cells. Since VEGF is known as a heavily glycosylated, 34-45 $\mathrm{kDa}$ dimeric protein [24], the higher molecular weight band was likely to be the glycosylated form of the VEGF $_{165}$ monomer. To determine whether the band was representing the glycosylated form of the protein, we treated HCT-116 cells with an N-glycosylation inhibitor tunicamycin (TN) and observed that TN treatment eliminated the upper band, indicating that the slower-migrating protein corresponded to the glycosylated form of VEGF $_{165}$ monomer (Figure 1B). The higher molecular weight bands are thought to be caused by non-specific antibody bindings since the bands remained unchanged under different denaturing conditions and their intensities did not change with overexpression or silencing of VEGF (data not shown).

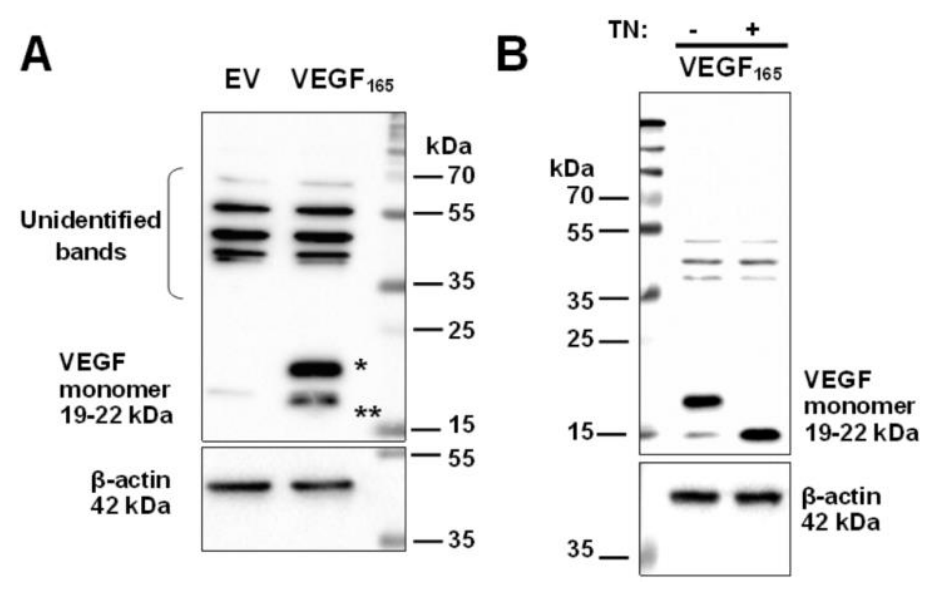

Figure 1. VEGF is glycosylated in HCT-116 cells: VEGF $_{165}$ is cloned into pcDNA3.1 (-) mammalian expression vector and HCT-116 cells were transiently transfected with pcDNA3.1 (-) vector (EV) or pcDNA3.1 (-) vector carrying VEGF $_{165}\left(\right.$ VEGF $\left._{165}\right)$. A. VEGF expression was determined by western blot after transient transfection for $24 \mathrm{~h}$. B. Following $24 \mathrm{~h}$ transfection, EV or VEGF ${ }_{165}$ transfected HCT-116 cells were treated with TN $(10 \mu \mathrm{g} / \mathrm{ml}, 24 \mathrm{~h})$ to determine $\mathrm{VEGF}_{165}$ glycosylation (*: glycosylated $\mathrm{VEGF}_{165}$; **: unglycosylated $\left.V_{E G F}{ }_{165}\right)$. "Unidentified bands" are thought to be caused by non-specific antibody bindings. $\beta$-actin was used as loading control.

\section{B. VEGF Overexpression Does Not Affect Proliferation of Colon Cancer Cells}

To investigate whether VEGF overexpression affects cellular proliferation, MTT assay was carried out with VEGF $_{165}$ or EV transfected HCT-116 cells. We found that VEGF overexpression did not alter viability or proliferation of HCT-116 cells (Figure 2A), although the overexpression enhanced VEGF secretion (Figure 2B and Figure 2C). Knowing that VEGF is highly glycosylated in HCT-116 cells (Figure 1B), we further 


\begin{tabular}{llr}
\hline \hline & $\begin{array}{l}\text { BŞEÜ Fen Bilimleri Dergisi } \\
\text { 7. Cilt - Milli Mücadele ve TBMM'nin }\end{array}$ & BSEU Journal of Science \\
Aç1lişının 100. Y1l Anısına-100. Y1l Özel & DOI: 10.35193/bseufbd. 631769 \\
& Sayıs1 & \\
& $329-343,2020$ & e-ISSN: 2458-7575 (http://dergipark.gov.tr/bseufbd) \\
\hline
\end{tabular}

investigated if TN (as a non-specific N-glycosylation inhibitor) affected the viability of HCT-116 cells. We observed that incubation with $10 \mu \mathrm{g} / \mathrm{ml} \mathrm{TN}$ for $24 \mathrm{~h}$ caused about $20 \%$ decrease in the viable cell number in both EV and $\mathrm{VEGF}_{165}$ transfected cells (Figure 2D and Figure 2E).
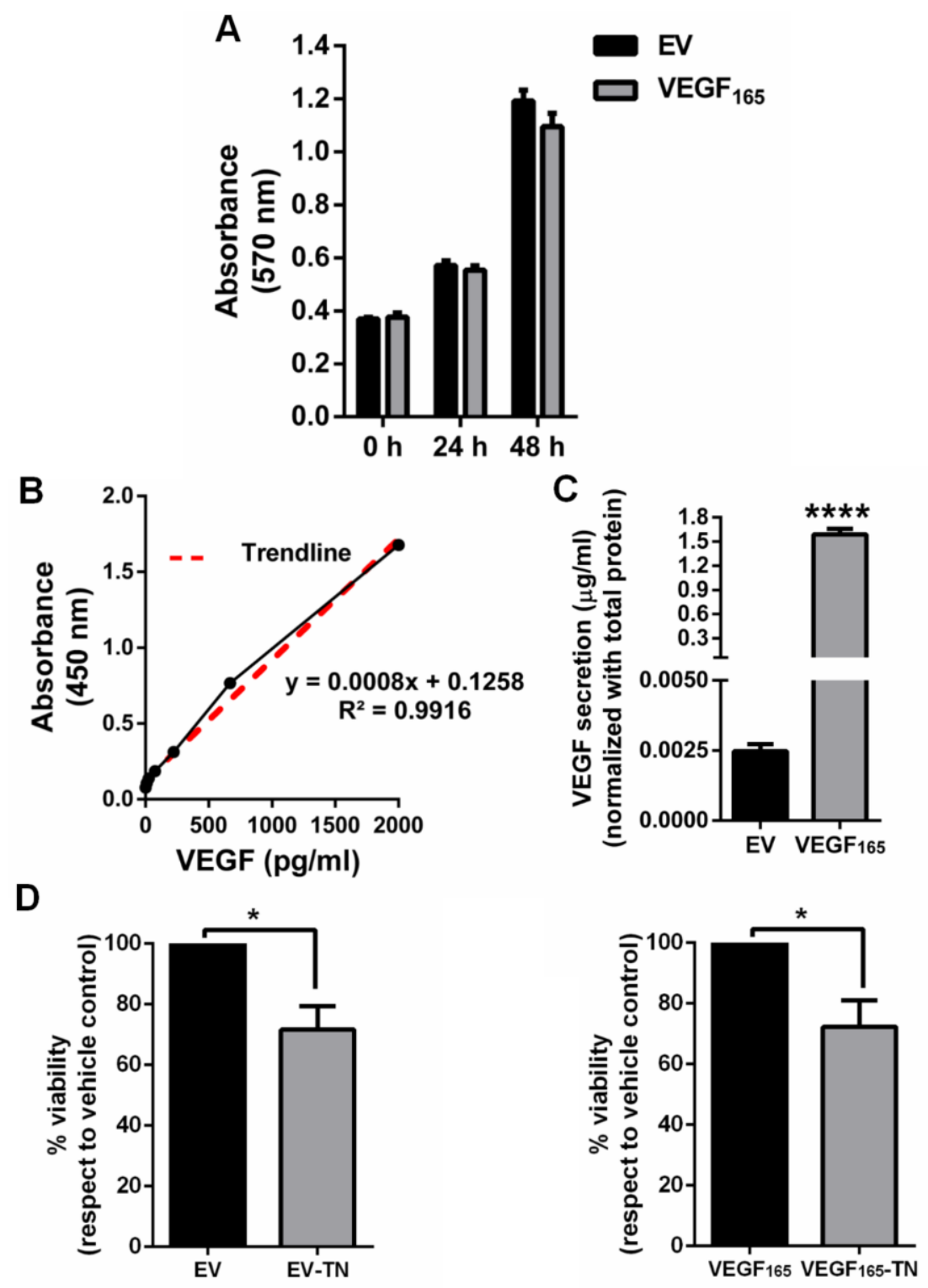

Figure 2. Effect of VEGF overexpression on cell proliferation: HCT-116 cells were transfected transiently with EV or $\mathrm{VEGF}_{165}$ expression vector. A. $24 \mathrm{~h}$ and $48 \mathrm{~h}$ after transfection, change in the number of viable cells was determined by MTT assay. The results belong to two independent biological replicates, each with eight technical replicates. B. Standart curve generated to detect secreted VEGF amount. C. Secreted VEGF was determined in EV and VEGF $_{165}$ transfected cells at $24 \mathrm{~h}$ post-transfection. The experiment was repeated two times with two technical replicates. D. Effect of TN $(10 \mu \mathrm{g} / \mathrm{ml}, 24 \mathrm{~h})$ treatment on cellular viability in EV and in E. VEGF 165 transfected HCT-116 cells. The experiments were repeated two times with eight technical replicates.

Interaction of VEGF with the VEGF receptors (VEGFRs) can activate MAPK (Mitogen-Activated Protein Kinase) pathways, including ERK (Extracellular-signal-Regulated Kinase), JNK (c-Jun N-terminal Kinase), and therefore contribute to tumor cell growth, survival, and migration $[25,26]$. In order to elucidate if VEGF overexpression could affect the VEGF-VEGFR related signaling pathways, we analyzed the activation of MAPK/ERK, MAPK/JNK and survival-associated PI3K/AKT pathways in EV or VEGF 165 transfected cells. We found that $\mathrm{VEGF}_{165}$ overexpression did not enhance VEGFR2 phosphorylation and did not further stimulate the 
activation of ERK1/2 and AKT (Figure 3A and B), supporting the MTT results which showed that VEGF 165 overexpression does not promote the proliferation of HCT-116 cells (Figure 2A). On the other hand, incubation with different doses of $\mathrm{TN}$, irrespective of the concentration, caused a drastic decrease in VEGFR2 phosphorylation without any change in total VEGFR2 amount (Figure 3A and D). On the contrary, total VEGFR1 level decreased substantially in TN treated cells (Figure 3D). Additionally, phosphorylation of ERK1/2 and AKT was also found to be decreased significantly in TN treated cells (Figure 3A, B and D). However, TN treatment increased JNK (p54 and p46) activation (Figure 3C), which indicates that decreased viability observed in TN treated cells could have resulted from the activation of JNK (Figure 2D and E), as described previously [27].

A

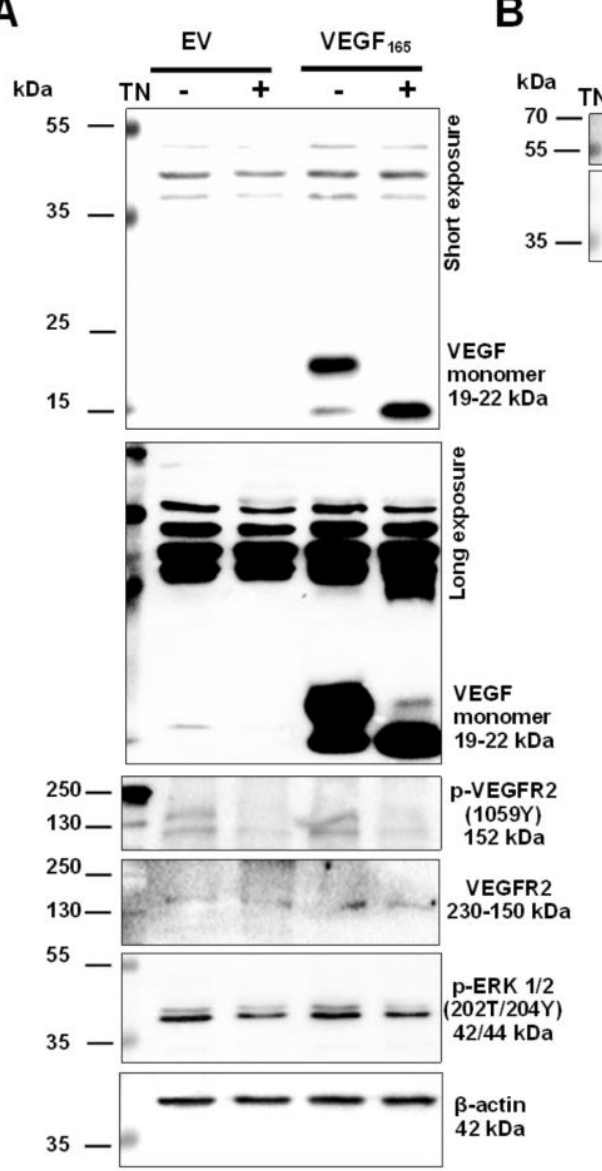

C

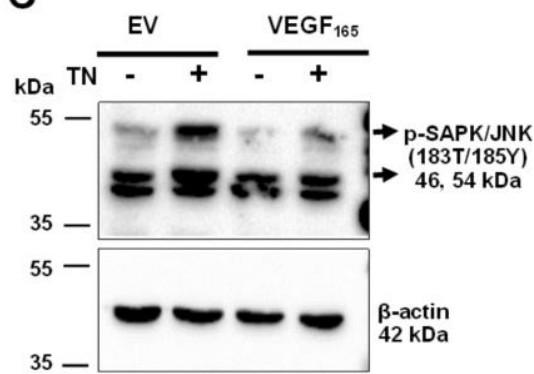

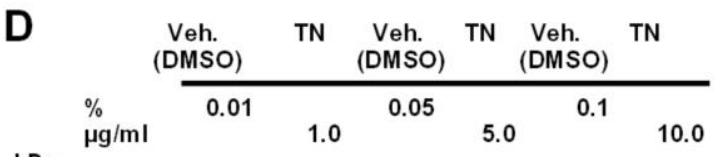

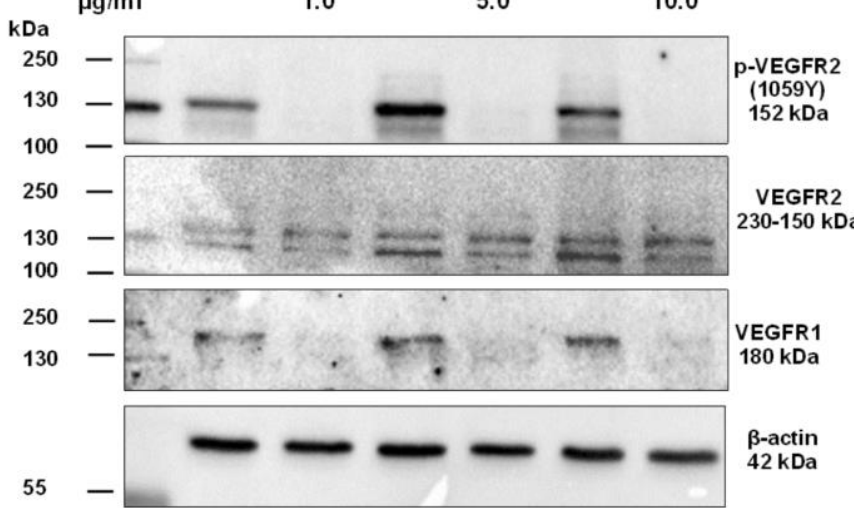

Figure 3. Evaluation of VEGF-VEGFR related signaling pathways in TN treated cells: Activation of VEGF related pathways were investigated in HCT-116 cells. A. Cells were transfected with EV or VEGF 165 for $24 \mathrm{~h}$, then treated with $10 \mu \mathrm{g} / \mathrm{ml} \mathrm{TN}$ for another $24 \mathrm{~h}$ and A. VEGFR2 and VEGFR2 phosphorylation and ERK phosphorylation, B. AKT phosphorylation, and C. JNK activation were investigated by western blot. D. Wild type HCT-116 cells were treated with different doses of TN for $24 \mathrm{~h}$ and western blot was used to determine VEGFR2, phopsho VEGFR2 and VEGFR1 levels. $\beta$-actin was used as loading control.

The lack of activation of MAPK signaling in VEGF overexpressing HCT-116 cells prompted us to suggest that VEGF does not have autocrine and/or intracrine effects on colon cancer cells. Therefore, to better investigate the effects of VEGF on intrinsic mitogen activated signals in colon cancer cells, we transiently silenced VEGF in HCT-116 cells. Silencing of VEGF was confirmed by reduced mRNA expression (Figure 4A) and reduced secretion (Figure 4B). In VEGF silenced cells, ERK and AKT phosphorylation were found to be diminished with respect to wild type cells (mock) or control siRNA transfected cells, but activation of VEGFR2 remained unaffected by the reduced level of cellular or secreted VEGF (Figure 4C). Collectively, VEGF overexpression and silencing experiments indicate that in the HCT-116 colon cancer cell line model, VEGF can function in an autocrine and/or intracrine manner, but it needs a partner to activate the downstream events. Since 
neither overexpression nor silencing of VEGF affected VEGFR2 phosphorylation, it can be suggested that the autocrine and/or intracrine activity of VEGF might depend on the availability and abundance of VEGF-VEGFR1 complex and cellular VEGFR1 level might limit the effectiveness of VEGF.

\section{As an ER Stress Inducer, Tunicamycin (TN) Enhances VEGF Expression and Secretion}

We then asked if inhibition of VEGF glycosylation has an impact on the observed decrease in the number of viable cells through decreased secretion of VEGF. Interestingly, inhibition of glycosylation by TN in HCT-116 cells significantly increased the VEGF secretion (Figure 5A). In other words, the number of viable cells were decreased with TN treatment, but this loss in cell number was not reflected in the secreted amount of VEGF. Thus, we analyzed VEGF mRNA levels in two colorectal cancer cell lines, HCT-116 and Caco-2, to see whether VEGF expression was enhanced in viable cells after TN treatment. We found increased VEGF mRNA levels in TN treated HCT-116 and Caco-2 cells in comparison with the corresponding vehicle treated controls (Figure 5B).

TN, an inhibitor of N-linked glycosylation, triggers ER stress by causing accumulation of unfolded proteins in the ER [28]. Analysis of GSE41666 beadchip array by GEO2R tool on GEO database confirmed the enhanced expression of VEGF in HCT-116 cells incubated with $1.5 \mu \mathrm{g} / \mathrm{ml}$ of $\mathrm{TN}$ for $24 \mathrm{~h}$. ( $\operatorname{LogFC}=1.53$; $\mathrm{p}=5.23 \mathrm{E}-4)$. Not only in colon cancer cells, TN was found to enhance VEGF expression also in HepG2 human liver cancer cells $(\operatorname{LogFC}=1.24 ; \mathrm{p}=6.13 \mathrm{E}-4)$ (Figure $5 \mathrm{C})$. Thapsigargin $(\mathrm{Tg})$ is another ER stress inducer. It is an inhibitor of the sarcoplasmic/endoplasmic reticulum $\mathrm{Ca}^{2+}$-ATPase (SERCA) pump and therefore causes ER stress by reducing ER calcium level [29]. GSE41666 dataset analysis revealed that VEGF expression increased in both HCT-116 ( $\operatorname{LogFC}=2.69 ; \mathrm{p}=1.5 \mathrm{E}-6)$ and HepG2 (LogFC=1.62; $\mathrm{p}=7.62 \mathrm{E}-5)$ cells treated with $0.3 \mu \mathrm{M} \mathrm{Tg}$ for $24 \mathrm{~h}$ (Figure 5D). Together with wet lab data, these results indicate that ER stress can enhance VEGF expression.
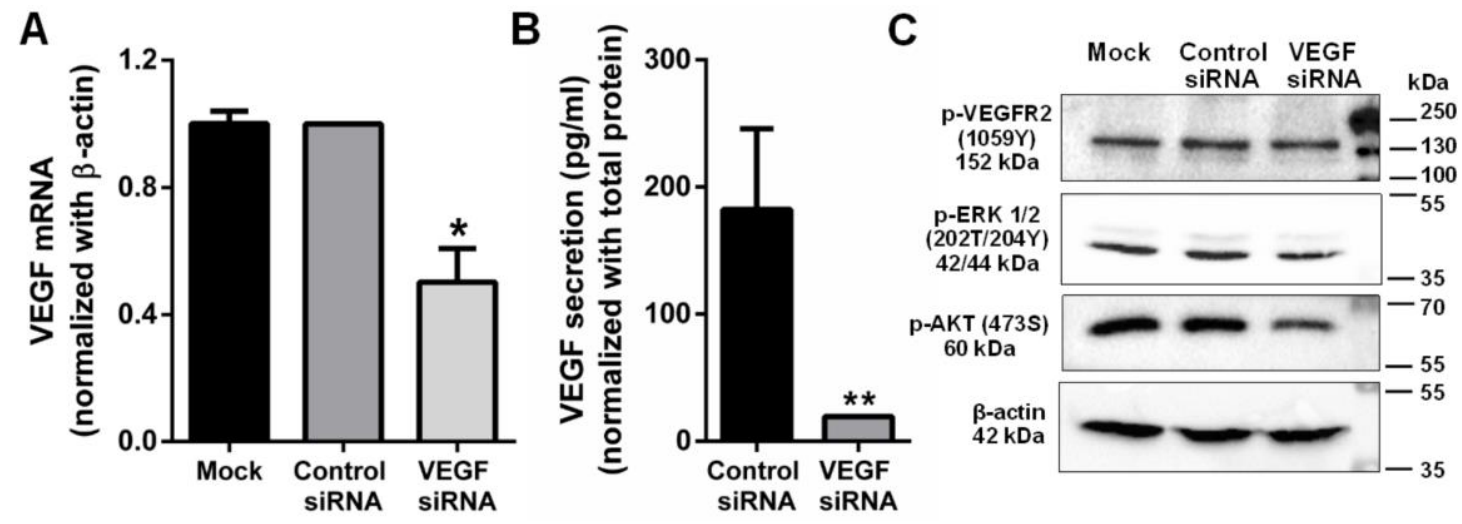

Figure 4. Silencing of VEGF in colon cancer cells inhibits mitogen-activated pathways: HCT-116 cells were transiently transfected with non-targeting siRNA duplex (Control siRNA) or with siRNA targeting VEGF (VEGF siRNA) or treated with transfection reagent (Mock). A. VEGF mRNA levels were determined in mock, control siRNA or VEGF siRNA tra nsfected cells by qRT-PCR. The experiment was repeated two times, each with three technical repliactes. Expression levels, normalized with $\beta$-actin, are given as "fold change" respect to mock controls. B. Quantitiy of VEGF secreted by control siRNA or VEGF siRNA transfected HCT-116 cells was determined via VEGF ELISA. The experiment performed two times with two technical replicates. C. Effects of VEGF depletion in VEGFR2, ERK 1/2 and AKT activations were analyzed by western blot. $\beta$-actin was used as loading control.

Calcium is a second messenger and its intracellular signaling regulates many different cellular events [30]. By perturbation of calcium homeostasis, i.e. depleted calcium in ER and increased calcium in cytosol, calcium-dependent chaperones lose their chaperoning activities, resulting in accumulation of unfolded proteins and activation of the UPR [31]. VEGF secretion was measured after incubation of HCT-116 cells with BAPTAAM, a membrane permeable intracellular $\mathrm{Ca}^{2+}$ chelator [32]. As can be seen in Figure 5E, cytosolic calcium depletion decreased secreted VEGF amount providing further evidence for the modulating effect of ER stress on VEGF expression and secretion. 
$\mathrm{TN}$, an inhibitor of N-linked glycosylation, triggers ER stress by causing accumulation of unfolded proteins in the ER [28]. Analysis of GSE41666 beadchip array by GEO2R tool on GEO database confirmed the enhanced expression of VEGF in HCT-116 cells incubated with $1.5 \mu \mathrm{g} / \mathrm{ml}$ of $\mathrm{TN}$ for $24 \mathrm{~h}$. ( $\operatorname{LogFC}=1.53$; $\mathrm{p}=5.23 \mathrm{E}-4)$. Not only in colon cancer cells, TN was found to enhance VEGF expression also in HepG2 human liver cancer cells $(\operatorname{LogFC}=1.24 ; \mathrm{p}=6.13 \mathrm{E}-4)$ (Figure $5 \mathrm{C})$. Thapsigargin $(\mathrm{Tg})$ is another ER stress inducer. It is an inhibitor of the sarcoplasmic/endoplasmic reticulum $\mathrm{Ca}^{2+}$-ATPase (SERCA) pump and therefore causes ER stress by reducing ER calcium level [29]. GSE41666 dataset analysis revealed that VEGF expression increased in both HCT-116 (LogFC=2.69; p=1.5E-6) and HepG2 (LogFC=1.62; p=7.62E-5) cells treated with $0.3 \mu \mathrm{M}$ Tg for $24 \mathrm{~h}$ (Figure 5D). Together with wet lab data, these results indicate that ER stress can enhance VEGF expression.

Calcium is a second messenger and its intracellular signaling regulates many different cellular events [30]. By perturbation of calcium homeostasis, i.e. depleted calcium in ER and increased calcium in cytosol, calcium-dependent chaperones lose their chaperoning activities, resulting in accumulation of unfolded proteins and activation of the UPR [31]. VEGF secretion was measured after incubation of HCT-116 cells with BAPTAAM, a membrane permeable intracellular $\mathrm{Ca}^{2+}$ chelator [32]. As can be seen in Figure 5E, cytosolic calcium depletion decreased secreted VEGF amount providing further evidence for the modulating effect of ER stress on VEGF expression and secretion.

\section{DISCUSSION}

VEGF-A (VEGF) is the most potent angiogenic cytokine which functions in the process of angiogenesis with mitogenic and vascular permeability-stimulating activities specific to endothelial cells [33]. VEGF can bind to VEGFR1 and VEGFR2, but the primary proangiogenic signal is claimed to be generated from VEGFactivated VEGFR2 which enhances the activity of MAPK pathway, leading to endothelial proliferation [6, 33]. While much is understood about the VEGF signaling and the effects on endothelial cells, less is defined about the regulation and the consequences of VEGF signaling in tumor cells [11].

Preclinical and clinical studies suggest that VEGF is the one of the foremost angiogenic factors in CRC. Half of the CRC cases are known to express high amounts of VEGF while the normal colonic mucosa and adenomas express minimal to no VEGF. CRC patients with high levels of VEGF expression show significantly worse survival when compared to those with weak or no expression [34]. Moreover, increased VEGF expression was found to be associated significantly with advanced lymph node status and distant metastasis in CRC [35]. In the current study, we showed that silencing of VEGF reduced MAPK/ERK activity and reduced the phosphorylation of AKT, a cell survival factor. Both VEGF overexpression and silencing experiments showed that in HCT-116 colon cancer cell line model, VEGFR2 activation was not affected by VEGF expression. In breast cancer, Lee at al. revealed that VEGF can act as a survival factor through its binding to VEGFR1 [36]. Bhattacharya et al. reported that VEGF is a survival factor in CRC cells and they suggested that VEGF-VEGFR1 complex interacts and inactivates an unidentified tyrosine phosphatase and decreased level of VEGF or VEGFR1 causes activation of this phosphatase [11]. Additionally, the authors found that depletion of VEGF receptor VEGFR1 by RNAi, mimicked the effects of VEGF depletion on AKT and ERK1/2 phosphorylation [11]. However, the authors did not emphasize the role of VEGFR2. Through both VEGF overexpression and VEGF siRNA approach, we suggest that autocrine and/or intracrine activity of VEGF may depend on VEGF-VEGFR1 complex and cellular VEGFR1 level might limit the mitogenic or survival effects of VEGF. Because it is known 


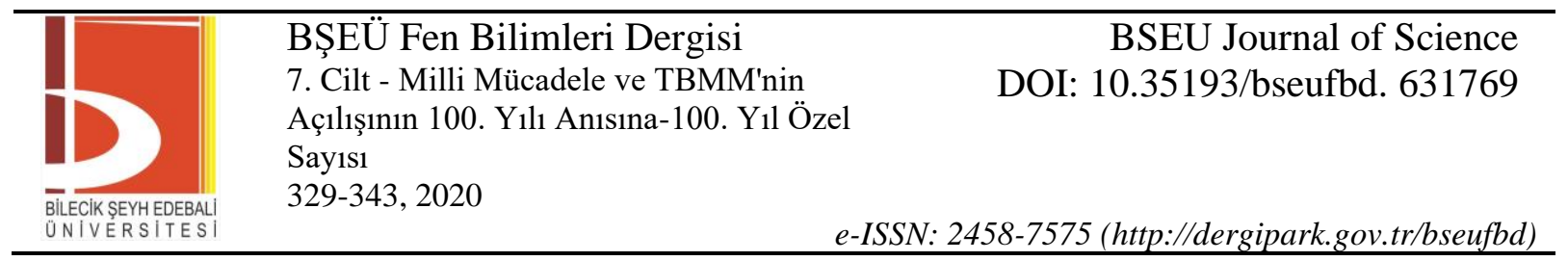

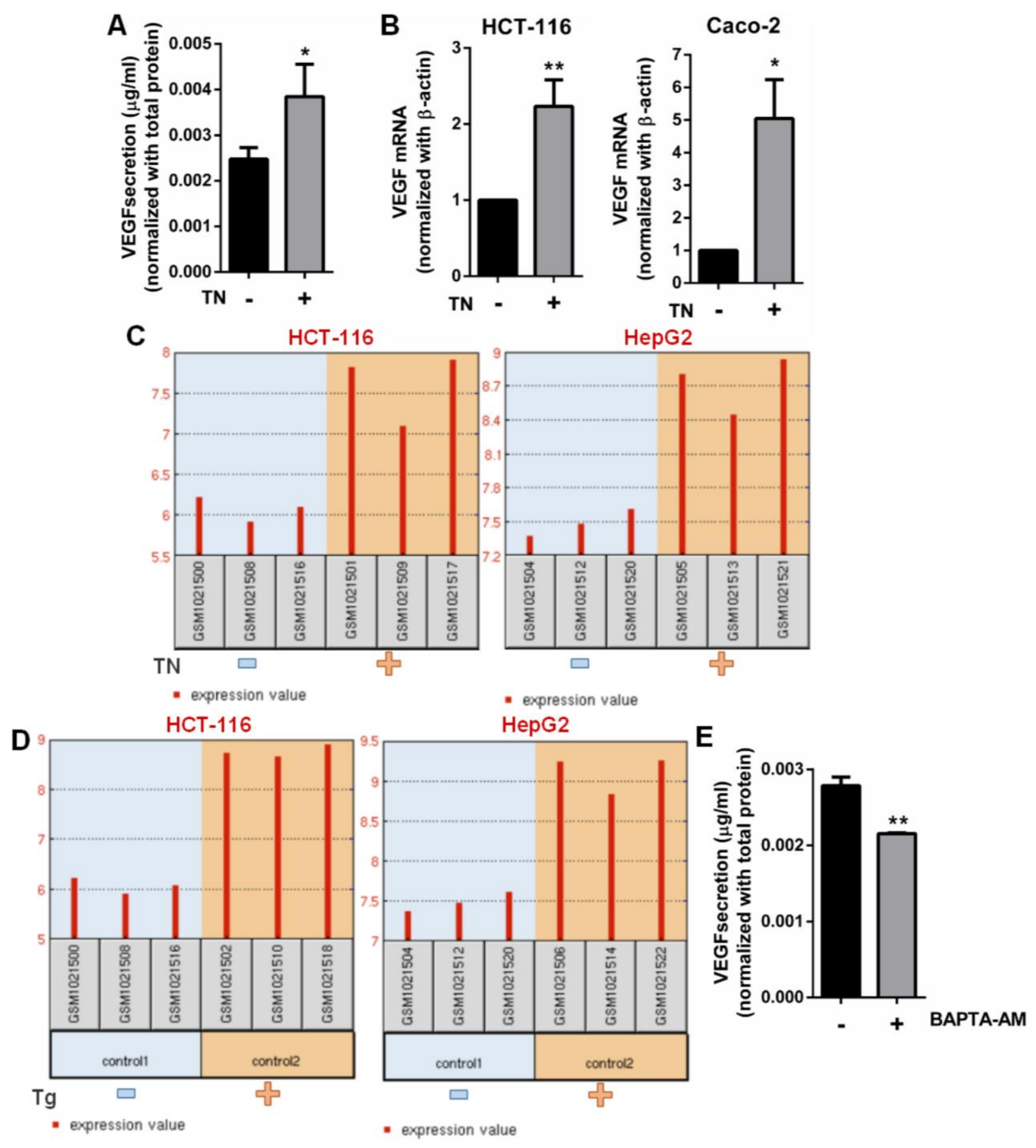

Figure 5. ER stress inducers enhance VEGF expression and secretion: Effects of ER stress inducers TN and Tg on VEGF mRNA and VEGF secretion levels were investigated. A. HCT-116 cells were treated with TN $(10 \mu \mathrm{g} / \mathrm{ml})$ for $24 \mathrm{~h}$ and secreted VEGF amount in vehicle treated or TN treated cells were determined by VEGF ELISA. Bars represent the average from two biological replicates, each having two technical repeats. B. HCT-116 or Caco-2 human colon cancer cells were analyzed for VEGF mRNA levels after TN treatment. Results obtained from two independent qRT-PCR experiments, each with three technical replicates, are shown. C. Analyses of GSE41666 array dataset show enhanced VEGF expression in TN or D. Tg treated human HCT-116 colon cancer cells and human HepG2 liver cancer cells. E. Secreted VEGF levels in BAPTA-AM treated or untreated control cells are given. Bars show average of two technical replicates. 
that resistance to anti-VEGF therapy occurs in $90 \%$ of patients with metastatic CRC [37], targeting VEGFVEGFR1 interaction can be a treatment option to manipulate VEGF dependent survival.

Since VEGF is a glycosylated protein, we also investigated the effect of inhibition of N-glycosylation by analyzing mitogen activated pathways. Inhibition of glycosylation by TN reduced cellular viability and decreased MAPK activity, however TN was found to stimulate JNK which is known to function upstream of autophagic and apoptotic pathways [38]. Following the inhibition of N-glycosylation by TN, VEGF secretion was found to be enhanced. This result was unexpected since TN treatment was observed to reduce cellular viability. On the other hand, we found that VEGF expression was enhanced in TN treated cells which was consistent with the observed increase in VEGF secretion. Furthermore, analysis of publicly available microarray dataset showed that Tg, another ER stress inducing agent, also enhanced the level of VEGF mRNA. Reduction of basal ER stress level by using the $\mathrm{Ca}^{2+}$ chelator BAPTA-AM supported our findings that ER stress induces VEGF secretion. Chronic activation of UPR is one of the characteristic of cancer cells and it is considered to contribute to tumor progression and resistance to apoptosis and anticancer treatments [19]. If UPR proteinfolding defect can not be resolved, severe and prolonged ER stress can cause cell death. Based on this argument, drugs to trigger extensive ER stress have been developed [21]. However, our results suggest that although ER stress decreases cancer cell viability, the surviving cells may be able to adapt to the stress by elevating VEGF expression, secretion and VEGF mediated signaling.

\section{CONCLUSION}

Including anti-VEGF therapies, the major obstacle during cancer treatment is the ability of cancer cells to develop resistance to therapeutics [39, 40]. Very recently, it has been reported that UPR is critical for resistance to chemo-therapeutics as an adaptive survival signaling [39]. Our results suggest that although stimulating UPR with pharmacological drugs could be an innovative therapeutic approach, this concept may not provide a valid anti-cancer strategy since through increased VEGF expression and secretion, solid tumors may gain resistance mechanisms for survival and neo-angiogenesis.

\section{ACKNOWLEDGEMENT}

Sinem Tunçer was supported by TÜBİTAK, 2218-National Postdoctoral Research Fellowship Program. The financial support of Banerjee Lab. is gratefully acknowledged. The authors would like to thank Aydan Torun for the technical support.

\section{REFERENCES}

[1] Schaaf, M. B., Garg, A. D., \& Agostinis, P. (2018). Defining the role of the tumor vasculature in antitumor immunity and immunotherapy. Cell Death Dis, 9(2), 115.

[2] Yang, J., Yan, J., \& Liu, B. (2018). Targeting VEGF/VEGFR to Modulate Antitumor Immunity. Front Immunol, 9, 978.

[3] Peach, C. J., Mignone, V. W., Arruda, M. A., Alcobia, D. C., Hill, S. J., Kilpatrick, L. E., \& Woolard, J. (2018). Molecular Pharmacology of VEGF-A Isoforms: Binding and Signalling at VEGFR2. Int J Mol Sci, 19(4).

[4] Guzman-Hernandez, M. L., Potter, G., Egervari, K., Kiss, J. Z., \& Balla, T. (2014). Secretion of VEGF165 has unique characteristics, including shedding from the plasma membrane. Mol Biol Cell, 25(7), 1061-1072.

[5] Dervenis, N., Mikropoulou, A. M., Tranos, P., \& Dervenis, P. (2017). Ranibizumab in the Treatment of Diabetic Macular Edema: A Review of the Current Status, Unmet Needs, and Emerging Challenges. $A d v$ Ther, 34(6), 1270-1282.

[6] Shibuya, M. (2011). Vascular Endothelial Growth Factor (VEGF) and Its Receptor (VEGFR) Signaling in Angiogenesis: A Crucial Target for Anti- and Pro-Angiogenic Therapies. Genes Cancer, 2(12), 1097 - 
1105.

[7] Shibuya, M. (2010). Tyrosine Kinase Receptor Flt/VEGFR Family: Its Characterization Related to Angiogenesis and Cancer. Genes Cancer, 1(11), 1119-1123.

[8] Pandey, A. K., Singhi, E. K., Arroyo, J. P., Ikizler, T. A., Gould, E. R., Brown, J., Beckman, J. A., Harrison, D. G, \& Moslehi, J. (2018). Mechanisms of VEGF (Vascular Endothelial Growth Factor) Inhibitor-Associated Hypertension and Vascular Disease. Hypertension, 71(2), e1-e8.

[9] Ahluwalia, A., Jones, M. K., Matysiak-Budnik, T., \& Tarnawski, A. S. (2014). VEGF and colon cancer growth beyond angiogenesis: does VEGF directly mediate colon cancer growth via a non-angiogenic mechanism? Curr Pharm Des, 20(7), 1041-1044.

[10] Yeh, C. C., Shih, L. J., Chang, J. L., Tsuei, Y. W., Wu, C. C., Hsiao, C. W., Chuu, C. P., \& Kao, Y. H. (2019). Synchronous vascular endothelial growth factor protein profiles in both tissue and serum identify metastasis and poor survival in colorectal cancer. Sci Rep, 9(1), 4228.

[11] Bhattacharya, R., Ye, X. C., Wang, R., Ling, X., McManus, M., Fan, F., Boulbes, D., \& Ellis, L. M. (2016). Intracrine VEGF Signaling Mediates the Activity of Prosurvival Pathways in Human Colorectal Cancer Cells. Cancer Res, 76(10), 3014-3024.

[12] Zhang, Q., Yu, C., Peng, S., Xu, H., Wright, E., Zhang, X., Huo, X., Cheng, E., Pham, T. H., Asanuma, K., Hatanpaa, K. J., Rezai, D., Wang, D. H., Sarode, V., Melton, S., Genta, R. M., Spechler, S. J., \& Souza, R. F. (2014). Autocrine VEGF signaling promotes proliferation of neoplastic Barrett's epithelial cells through a PLC-dependent pathway. Gastroenterology, 146(2), 461-472 e466.

[13] Santos, S. C., \& Dias, S. (2004). Internal and external autocrine VEGF/KDR loops regulate survival of subsets of acute leukemia through distinct signaling pathways. Blood, 103(10), 3883-3889.

[14] Lichtenberger, B. M., Tan, P. K., Niederleithner, H., Ferrara, N., Petzelbauer, P., \& Sibilia, M. (2010). Autocrine VEGF signaling synergizes with EGFR in tumor cells to promote epithelial cancer development. Cell, 140(2), 268-279.

[15] Ohba, T., Cates, J. M., Cole, H. A., Slosky, D. A., Haro, H., Ando, T., Schwartz, H. S., \& Schoenecker, J. G. (2014). Autocrine VEGF/VEGFR1 signaling in a subpopulation of cells associates with aggressive osteosarcoma. Mol Cancer Res, 12(8), 1100-1111.

[16] Barr, M. P., Gray, S. G., Gately, K., Hams, E., Fallon, P. G., Davies, A. M., Richard, D. J., Pidgeon, G. P., \& O'Byrne, K. J. (2015). Vascular endothelial growth factor is an autocrine growth factor, signaling through neuropilin-1 in non-small cell lung cancer. Mol Cancer, 14, 45.

[17] Masood, R., Cai, J., Zheng, T., Smith, D. L., Hinton, D. R., \& Gill, P. S. (2001). Vascular endothelial growth factor (VEGF) is an autocrine growth factor for VEGF receptor-positive human tumors. Blood, 98(6), 1904-1913.

[18] Corazzari, M., Gagliardi, M., Fimia, G. M., \& Piacentini, M. (2017). Endoplasmic Reticulum Stress, Unfolded Protein Response, and Cancer Cell Fate. Front Oncol, 7, 78.

[19] Sisinni, L., Pietrafesa, M., Lepore, S., Maddalena, F., Condelli, V., Esposito, F., \& Landriscina, M. (2019). Endoplasmic Reticulum Stress and Unfolded Protein Response in Breast Cancer: The Balance between Apoptosis and Autophagy and Its Role in Drug Resistance. Int J Mol Sci, 20(4).

[20] Poplawski, T., Pytel, D., Dziadek, J., \& Majsterek, I. (2019). Interplay between Redox Signaling, Oxidative Stress, and Unfolded Protein Response (UPR) in Pathogenesis of Human Diseases. Oxid Med Cell Longev, 2019, 6949347.

[21] Wang, M., Law, M. E., Castellano, R. K., \& Law, B. K. (2018). The unfolded protein response as a 
target for anticancer therapeutics. Crit Rev Oncol Hematol, 127, 66-79.

[22] Pfaffl, M. W. (2001). A new mathematical model for relative quantification in real-time RT-PCR. Nucleic Acids Res, 29(9), e45.

[23] Bustin, S. A., Benes, V., Garson, J. A., Hellemans, J., Huggett, J., Kubista, M., Mueller, R., Nolan, T., Pfaffl, M. W., Shipley, G. L., Vandesompele, J., \& Wittwer, C. T. (2009). The MIQE guidelines: minimum information for publication of quantitative real-time PCR experiments. Clin Chem, 55(4), 611622.

[24] Aldebasi, Y. H., Rahmani, A. H., Khan, A. A., \& Aly, S. M. (2013). The effect of vascular endothelial growth factor in the progression of bladder cancer and diabetic retinopathy. Int J Clin Exp Med, 6(4), 239-251.

[25] Podar, K., \& Anderson, K. C. (2005). The pathophysiologic role of VEGF in hematologic malignancies: therapeutic implications. Blood, 105(4), 1383-1395.

[26] Ratnasari, N. \& Yano, Y. (2015). "Do Soluble Vascular Endothelial Growth Factor and Its Receptors Predict the Progression of Chronic Hepatitis to Hepatocellular Carcinoma ?," J. Hepat., no. Il, pp. 2-5.

[27] Liu, Y., Feng, J., Zhao, M., Wu, J., Fan, J., Wen, Q., Xu, J., Zhang, J., Fu, S., Wang, B., Lu, Y., Xiong, K., Xiang, L., Zhang, Y., \& Yang, L. (2017). JNK pathway inhibition enhances chemotherapeutic sensitivity to Adriamycin in nasopharyngeal carcinoma cells. Oncol Lett, 14(2), 1790-1794.

[28] Shen, M., Wang, L., Guo, X., Xue, Q., Huo, C., Li, X., Fan, L., \& Wang, X. (2015). A novel endoplasmic reticulum stressinduced apoptosis model using tunicamycin in primary cultured neonatal rat cardiomyocytes. Mol Med Rep, 12(4), 5149-5154.

[29] Oslowski, C. M., \& Urano, F. (2011). Measuring ER stress and the unfolded protein response using mammalian tissue culture system. Methods Enzymol, 490, 71-92.

[30] Berridge, M. J., Lipp, P., \& Bootman, M. D. (2000). The versatility and universality of calcium signalling. Nat Rev Mol Cell Biol, 1(1), 11-21.

[31] Mendez, J. M., Kolora, L. D., Lemon, J. S., Dupree, S. L., \& Keestra-Gounder, A. M. (2019). Activation of the Endoplasmic Reticulum Stress Response Impacts the NOD1 Signaling Pathway. Infect Immun, 87(8).

[32] Wie, M. B., Koh, J. Y., Won, M. H., Lee, J. C., Shin, T. K., Moon, C. J., Ha, H. J., Park, S. M., \& Kim, H. C. (2001). BAPTA/AM, an intracellular calcium chelator, induces delayed necrosis by lipoxygenasemediated free radicals in mouse cortical cultures. Prog Neuropsychopharmacol Biol Psychiatry, 25(8), 1641-1659.

[33] Ferrara, N. (2004). Vascular endothelial growth factor: basic science and clinical progress. Endocr Rev, 25(4), 581-611.

[34] Bendardaf, R., Buhmeida, A., Hilska, M., Laato, M., Syrjanen, S., Syrjanen, K., Collan, Y., \& Pyrhonen, S. (2008). VEGF-1 expression in colorectal cancer is associated with disease localization, stage, and long-term disease-specific survival. Anticancer Res, 28(6B), 3865-3870.

[35] Bendardaf, R., El-Serafi, A., Syrjanen, K., Collan, Y., \& Pyrhonen, S. (2017). The effect of vascular endothelial growth factor-1 expression on survival of advanced colorectal cancer patients. Libyan J Med, $12(1), 1290741$.

[36] Lee, T. H., Seng, S., Sekine, M., Hinton, C., Fu, Y., Avraham, H. K., \& Avraham, S. (2007). Vascular endothelial growth factor mediates intracrine survival in human breast carcinoma cells through internally expressed VEGFR1/FLT1. PLoS Med, 4(6), e186. 
[37] Hammond, W. A., Swaika, A., \& Mody, K. (2016). Pharmacologic resistance in colorectal cancer: a review. Ther Adv Med Oncol, 8(1), 57-84.

[38] Liu, X., Zhao, P., Wang, X., Wang, L., Zhu, Y., \& Gao, W. (2019). Triptolide Induces Glioma Cell Autophagy and Apoptosis via Upregulating the ROS/JNK and Downregulating the Akt/mTOR Signaling Pathways. Front Oncol, 9, 387.

[39] Bahar, E., Kim, J. Y., \& Yoon, H. (2019). Chemotherapy Resistance Explained through Endoplasmic Reticulum Stress-Dependent Signaling. Cancers (Basel), 11(3).

[40] Al-Abd, A. M., Alamoudi, A. J., Abdel-Naim, A. B., Neamatallah, T. A., \& Ashour, O. M. (2017). Antiangiogenic agents for the treatment of solid tumors: Potential pathways, therapy and current strategies A review. J Adv Res, 8(6), 591-605. 